\title{
An Effective Treatment Regimen for Warts in Cattle
}

\author{
Mathi $\mathrm{PM}^{1}$, Saranya $\mathrm{K}^{2}$, Umadevi $\mathrm{U}^{3}$ and Umakanthan $\mathrm{T}^{* 4}$ \\ ${ }^{1}$ Veterinary practitioner, V. P. Palayam, Unjalur, Erode, Tamilnadu, India \\ ${ }^{2}$ Veterinary practitioner, Satur, Virudhunagar, Tamilnadu, India \\ ${ }^{3}$ Assistant Professor, Department of Botany with Biotechnology, Standard Fireworks Rajarathinam College for \\ Women, Sivakasi, Virudhunagar, Tamilnadu, India \\ ${ }^{4}$ Veterinary Surgeon, Veterinary Hospital, Satur, Virudhunagar, Tamilnadu, India
}

*Corresponding author: Umakanthan T, Veterinary Surgeon, Veterinary Hospital, Satur, Virudhunagar, Tamilnadu, India 626203, E-mail: jailani8319@gmail.com

Citation: Mathi PM, Saranya K, Umadevi U, Umakanthan T (2016) An Effective Treatment Regimen for Warts in Cattle. J Vet Sci Ani Husb 4(2): 202. doi: 10.15744/2348-9790.4.202

Received Date: February 17, 2016 Accepted Date: May 23, 2016 Published Date: May 25, 2016

\begin{abstract}
The study was aimed to evaluate the potency and for advocation of a homeopathic drug regimen against warts. Sixty six cattle of variable age presented with warts on skin, eyelids, ears, muzzle, udder and external genitals. Sixty were sublingually treated with Thuja drops $200 \mathrm{C}$ one $\mathrm{ml}$ twice daily for first 7 days and one $\mathrm{ml}$ once daily for next 23 days. Thuja ointment applied topically twice daily for 30 days. $95 \%$ recovery noticed in 30 days with no recurrence on 3 years observation. Six controlled animals showed no cure.

Keywords: Cattle; Warts; Homeopathic drug; Thuja
\end{abstract}

\section{Introduction}

The common wart, Verruca vulgaris, is a specific type of epithelial skin overgrowth, non-malignant in character. Warts are of common occurrence in cattle of all age groups on various parts of the body. The four most common types are squat, pedunculated, and flat and tags. Though warts are little harm and disappear spontaneously over long time, but with recurrence they degrade the value of animal. Surgery and vaccination, or a combination of both, are the most common forms of treatment and prevention. There are no present literatures which reveal the exact drug regimen assuring no recurrence.

\section{Material and Method}

In different season and time, 66 cross bred cattle of different age were employed in this study. Clinical examination revealed warts of variable size and shape, smooth/hard, soft/firm, sessile/pedunculated and with/without maggots \& bleeding, on skin, eyelids, ears, muzzle, udder and external genitals. 60 animals were used for trial and 6 as control.

\section{Treatment and Result}

All the 60 trial animals were treated sublingually with Thuja drops (Sarada Homeo Lab - Kolkata) 200C one ml twice daily for 7 days followed by one $\mathrm{ml}$ once a day for next 23 days and Thuja ointment (Sarada Homeo Lab- Kolkata) applied over the warts twice daily for 30 days. Maggots treated appropriately. No other treatment given. The warts were found completely receded within 30 days and no recurrence seen on 3 years observation. Control animals showed no cure. Due to field limitations, identification and typing of causative organism not done. The animals presented in both the groups were heterogenous in all aspects.

\section{Discussion}

Warts are a type of tumour which is inactive or benign. Most are believed to be caused by viruses [1]. Skin warts frequently occur in young calves less than 2 years of age, and on teats and udder, and penis in mature cattle [2]. In younger animals, they appear around the eyes, mouth, ears, on the sides of the neck, and on the shoulders. Vary in size from pea-sized nodules to large pendulous cauliflower-like growths. The condition can spread and cover large areas of the body as numerous nodules or large masses, which are either hard or soft to the touch. The soft areas bleed easily and have a tendency to slough off giving an offensive odour $[1]$. 
As cited by Thomas and Simon, 2008 [3], skin warts usually are self-limiting within 1 to 12 months and treatment seldom is necessary. However, variable duration of warts before self-cure causes owners to request treatment. In addition various treatments, vaccines, quack medications gained acceptance because owners attribute eventual resolution of warts to treatment with those products, rather than spontaneous cure. Many substances have been used successfully in treatment, but results are variable. Surgical removal is recommended, but should be taken so warts do not generate [1]. Commercial or autogenous vaccines have been used extensively; unfortunately they suffer some major deficiencies like virus strains, efficacy to cure, etc. [3].

John McKenna, 1998 [4], cited that Dr. Warnatz, 1838 and Dr. Halter, 1949, successfully used Thuja topically and internally respectively for warts in human. The above drug with modified dosage in cattle proved $95 \%$ success. Bovine papilloma virus is one among the cause for warts. Thuja occidentalis, the tree of life, has strong antiviral properties [4]. This also deserves further research.

Thuja 30c or 200c was recommended as an important therapy for pedunculated warts once daily for fourteen days in cattle [5], but its effectiveness in curing and preventing the recurrence is obscure. Physiological provings of Thuja on animals, are as yet wholly wanting, still this is an admirable remedy [6]. In this paper, a definitive homeopathic regimen was advocated for treatment of warts and prevention of its recurrence.

\section{Summary}

Warts in cattle effectively treated without recurrence using homeopathic drug, Thuja - oral drops and ointment.

\section{Acknowledgement}

The authors thankfully acknowledge the support of cattle owners, field veterinarians and homeopathic practitioners.

\section{References}

1. Hoard's Dairyman (1993) Herd Health, W.D. Hoard \& Sons Company, USA.

2. Hagan WA, Bruner DW, Timoney JF (1988) Hagan and Bruner's Microbiology and Infectious Diseases of Domestic Animals ( $8^{\text {th }}$ Edn), Cornell University Press, USA.

3. Divers TJ, Peek SF (2008) Rebhun's Diseases of Dairy Cattle. Saunders Elsevier, USA.

4. McKenna J (1998) Natural Alternatives to Antibiotics, Avery Publishing group, USA.

5. Grey, Hampel (1847) The Homeopathic Examiner vol II, Leavitt, Tsow \& Co., Printers.

6. Macleod G (2012) The Treatment of Cattle by Homoeopathy, The C.W. Daniel publisher, England.

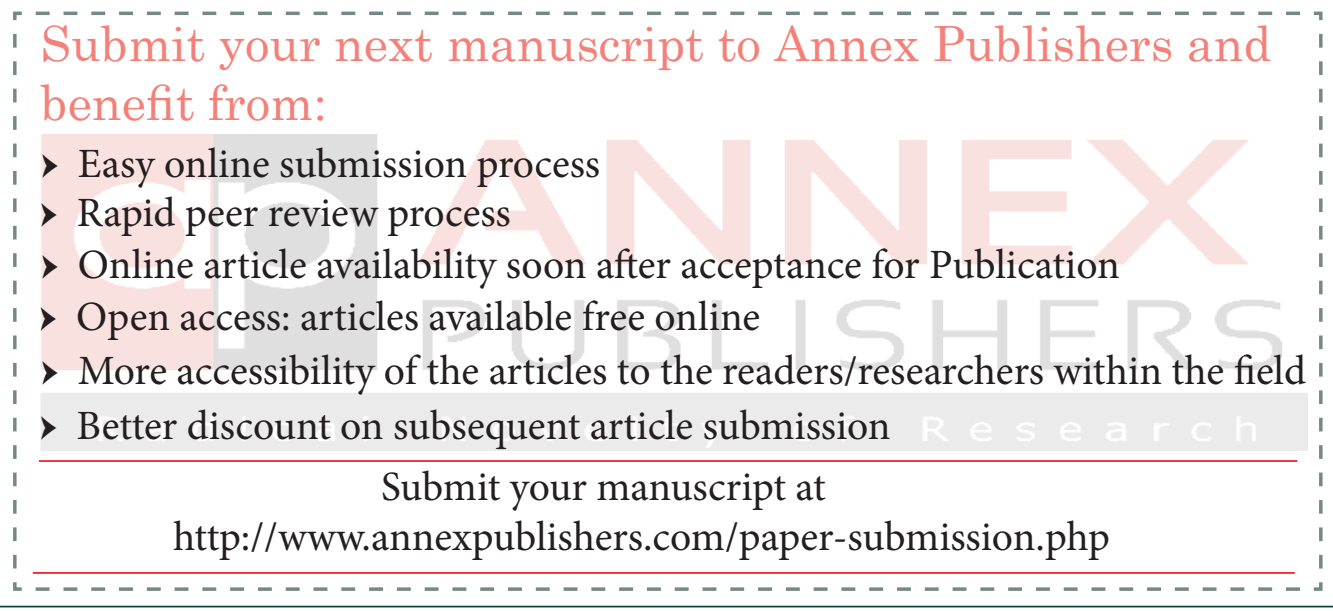

